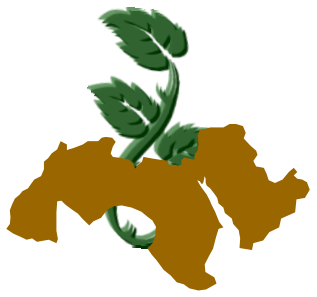

\title{
CHEMICAL COMPOSITION OF CAMEL'S COLOSTRUM AND MILK IN UNITED ARAB EMIRATES
}

\author{
Rea H. Omer ${ }^{1(a)}$ and A.H. Eltinay ${ }^{2}$ \\ 1- School of Food Technology, Faculty of Agricultural Technology and Fish Sciences, University \\ of Alneelain, Khartoum, Sudan \\ a) Email: reaho2006@yahoo.com \\ 2- Department of Food Science and Technology, Faculty of Agriculture Sciences, University of \\ Khartoum, Sudan
}

[9]

Keywords: Camel's colostrum, Camel's milk, Milk chemical composition, Milk minerals content

\begin{abstract}
The chemical composition of 350 samples from camel's colostrum and milk in United Arab Emirates were studied. Results of colostrum showed 6.19 for $\mathrm{pH}, 1.041 \mathrm{~g} / \mathrm{ml}$ for density, $3.1 \%$ for fat, $4.95 \%$ for protein, $4.4 \%$ for lactose, $12.88 \%$ for total solids, $10.55 \%$ for non fat total solids, $1.11 \%$ for ash, $87 \%$ for moisture .For mature milk, data were 6.6 for $\mathrm{pH}, 0.133 \%$ for acidity, $1.028 \mathrm{~g} / \mathrm{ml}$ for density, $3.2 \%$ for fat, $2.4 \%$ for protein, $4.6 \%$ for lactose, $11 \%$ for total solids, $7.88 \%$ for non-fat total solids, $0.88 \%$ for ash, and $88.9 \%$ for moisture. The minerals contents in camel colostrum were (mg/100mg) as follows: 103 for calcium, 15.4 for magnesium, 14.0 for sodium, 128 for potassium, 0.25 for iron, 0.17 for copper and 43.4 for inorganic phosphate. Elements in mature camel milk were $(\mathrm{mg} / 100 \mathrm{mg})$ as follows: 74.67 for calcium, 3.4 for magnesium, 42.36 for sodium, 136.64 for potassium, 0.18 for iron, 0.04 for copper, 0.02 for manganese, 0.3 for zinc and 38.4 for phosphorus.
\end{abstract}

\section{INTRODUCTION}

The dromedary, the one - humped or Arabian camel (Camelus dromedarius) is living in the arid and desert lands of Africa and Asia, where it is used as provider of both milk and meat for the desert dwellers (Bedouins) under extremely hostile conditions of temperature and scarcity of water and feed.
The total population of camel in the world is about 19 million, of which 14 million are in Africa and Near East, and 4.9 million in Asia (FAO/ WHO/ OIE, 1992). In Africa the dromedary is found in Morocco, Algeria, Tunisia, Libya, Egypt, Sudan, Mali, Ethiopia, Djibouti, Somalia, Kenya, Nigeria, Mauritania, Chad, Niger, Senegal, Upper Volta and Western Sahara. In Asia it occurs in Saudi Arabia, Syria, Jordan, Lebanon (Seasonally), Oman, Yemen, Israel, Iraq, United Arab Emirates, North West India, Pakistan, Turkey, Iran, Turkmenistan, Afghanistan and Western Sinking (China) (Gauthier - Pilters and Dagg, 1981).

Camels unlike other milk-producing animals can thrive under extreme hostile conditions of temperature, draught and lack of pastures and can still produce milk of high nutritional quality (Yagil and Elzion, 1980).

The composition of camel milk depends on many factors such as season, lactation period, feeding conditions, and water availability. Several studies had been carried out about the chemical composition, minerals content and nutrition quality of camel's colostrum and milk (Ohri and Joshi, 1961; Abdel Rahim, 1987; Abu-Lehia, 1987; Hagrass et al 1987; Yagil, 1987; Ahmed, 1988; Wahba et al 1988; Abu-lehia, 1989; Bayomi, 1990; Elamin, and Wilcox, 1992; Mehaia et al 1995; Gorban, and Izzeldin, 1997; and Wangoh et al 1998).

The aim of the present study was to through some light on the gross composition and minerals content of camel's colostrum and milk in United Arab Emirates. 


\section{MATERIALS AND METHODS}

\section{Collection of milk samples}

Camels milk samples (colostrum or mature milk) were collected from 350 lactating camels, from private camel herds, from Central (Alrawi) and Southern (Al Ain) regions of United Arab Emirates. All camels were in mid lactation (2nd to 5th month of lactation) except samples of colostrum which were taken when available. Camels of the same herd consumed the same type of feed. A box containing ice was used to provide cold storage during transportation to the laboratory to be analyzed as soon as possible.

\section{Sample containers}

1000 and $250 \mathrm{ml}$, autoclavable plastic containers were used for the collection of samples. Containers were sterilized at $120^{\circ} \mathrm{C}$ for $15 \mathrm{~min}$. and kept ready for milk collection from different sites.

\section{Chemicals}

All chemicals used were analytical grade. The standards for mineral determinations were from Merck (Darmstadt, Germany).

\section{Preparation of the udder}

Healthy and uninfected camels were used for milk collection. The udder was cleaned and washed with disinfectant solution (Safflon; 20\% concentration.) and was kept on the udder 5-10 min. before collection of samples. Twenty $\mathrm{ml}$ of the first milk leaving the udder were discarded.

\section{Interviewing owners of the animals}

All owners of the camels from which milk or colostrum samples were collected and were interviewed concerning lactating period, age of animals, duration of lactation, numbers of offspring per delivery, any sign of infection to udder, quantity of milk, and any related remarks on milk quality.

\section{Types of analysis conducted}

The following parameters were analyzed: $\mathrm{pH}$ as well as acidity, density, ash, moisture, fat, protein, lactose, and total solids contents. Also, all samples were analysed for their $\mathrm{Ca}, \mathrm{Mg}, \mathrm{P}, \mathrm{Na}, \mathrm{K}$, $\mathrm{Cu}, \mathrm{Fe}, \mathrm{Mn}$ and $\mathrm{Zn}$ contents.

\section{Preparation of the sample}

The sample was brought to $20^{\circ} \mathrm{C}$, mixed until homogenized and promptly weighed. In case that lumps of cream don't disperse, the milk was warmed in water bath to $38^{\circ} \mathrm{C}$ and kept mixed until homogeneous, then the sample was cooled to $20^{\circ} \mathrm{C}$.

\section{pH determination}

The $\mathrm{pH}$ of the milk was determined by a $\mathrm{pH}$ meter at $25^{\circ} \mathrm{C}$ according to APHA (1972).

Acidity, density, gross composition and minerals determinations

The acidity, density, total solids, ash, lactose and protein contents were determined according to AOAC (1995) methods. Fat content was determined according to Rose Gottleb method (Ling, 1963). Minerals content was determined according to the method described by Osborne and Voagt (1978).

All the elements were determined with UNICAM 939/959 atomic absorption spectrometer, with Optilex 466/Le Dekk and Epson FX870 printer.

\section{Data analysis}

SAS program was used for the data analysis (SAS, 1997).

\section{RESULTS AND DISCUSSION}

Tables (1 and 2) represent the physicochemical characteristics of colostrum and mature camel milk.

\section{The pH}

The $\mathrm{pH}$ of colostrum ranged from 6.0 to 6.3 with a mean value of 6.2 , and this is higher than Indian camel colostrum (5.6), as reported by Ohri and Joshi (1961), but lower than Saudi Arabia camel colostrum (Najdi-6.6, Genadria region-6.4) as reported by Abu-Lehia et al (1989) and Gorban and Izzeldin (1997). The $\mathrm{pH}$ of mature camel milk ranged from 6.4 to 6.7 with a mean value of 6.6, this was the same as those found by Mohamed (1990) and Ahmed (1988) for Somali and United Arab Emirates camel milk respectively. The $\mathrm{pH}$ of mature camel milk was similar to the $\mathrm{pH}$ of cow milk as reported by Mehaia (1995).

Titratable acidity 
The titratable acidity of mature camel milk ranged from $0.1 \%$ to $0.17 \%$ with a mean value $0.13 \%$. It is lower than those reported by AbuLehia (1987), Elamin and Wilcox (1992), Mehaia et al (1995) for Saudi Arabia camel milk, but higher than Iran camel milk $(0.2 \%)$ obtained by Karim and Gooklani (1987), and Ahmed (1988). It is worthmentioning here that the acidity of camel milk is still of particular importance in determining the freshness and keeping quality of camel milk. Ohri and Joshi (1961) found that the acidity of camel milk $2 \mathrm{~h}$ after milking was low $(0.03 \%)$ and increased to $0.14 \%$ in $6 \mathrm{~h}$, which was much slower than that found in cow milk.

\section{Specific gravity}

The specific gravity of camel colostrum ranged from $1.032 \mathrm{~g} / \mathrm{ml}$ to $1.050 \mathrm{~g} / \mathrm{ml}$ with a mean value of $1.041 \mathrm{~g} / \mathrm{ml}$ (Table 1), it is slightly lower than that reported by Gorban and Izzeldin (1997). Mature milk specific gravity ranged from $1.025 \mathrm{~g} / \mathrm{ml}$ to $1.032 \mathrm{~g} / \mathrm{ml}$ with a mean value of $1.028 \mathrm{~g} / \mathrm{ml}$ (Table 2). It is relatively similar to that obtained by Ahmed (1988), and Mohamed (1990), for UAE, camel milk $(1.027 \mathrm{~g} / \mathrm{ml})$, and Somali camel milk $(1.026 \mathrm{~g} / \mathrm{ml})$, respectively. Our results are slightly lower than those reported for Saudi Arabia camel milk (1.032g/ml, (Gorban and Izzeldin 1997), and Irani camel milk (1.031 $\mathrm{g} / \mathrm{ml}$, (Karim and Gooklani, 1987).

\section{Fat content}

The fat content of the dromedary camel colostrum ranged from $0.4 \%$ to $3.92 \%$ with a mean value of $3.1 \%$. This mean value is the same as that reported by Gorban and Izzeldin (1997), but some what higher than those reported by Johnson (1978) being 1.36\%, Ohri and Joshi (1961) being $0.2-2.8 \%$, and Yagil and Elzion (1980) being $0.15 \%$. The fat content of mature milk ranged from $1.1 \%$ to $5.3 \%$ with a mean value $3.2 \%$, which is comparable to that of cow milk. Our data agree with those obtained by Elamin and Wilcox (1992) being 3.2\%, Mehaia (1995) and Farah (1993) being $3.2 \%$ for Saudi Arabia and Kenya camels, respectively. It is substantially lower than those reported by Mohamed (1990) being 4.6\%, Karim and Gooklani (1987) being 4.2\%, Ahmed (1988) being $3.5 \%$ and Bayoumi (1990) being $3.6 \%$.

\section{Protein content}

Protein content varied between $3.7 \%$ to $7.0 \%$ with a mean value $5.0 \%$ for colostrum (Table 1). This is close to that obtained by Gorban and Izzeldin (1997), and from $1.3 \%$ to $3.83 \%$ with a mean value $2.4 \%$ for mature camel milk (Table 2), which are within the range of Pakistani camel milk (2.2-2.6\%), and the same as that for Saudi Arabia reported by Abu-Lehia (1987). Camel milk protein tends to decrease with the stage of lactation, where higher protein content $(4.95 \%)$ at colostrum and low protein content at mature stage (2.4\%). Abu-Lehia (1989) observed a sharp decline in protein from $13 \%$ to $5 \%$ within the first 24 hours and it continued decreasing gradually to reach $4 \%$ at the tenth day of lactation. Such trend was observed in the Indian camel colostrum (Ohri and Joshi, 1961), where the protein content decreased from $14.5 \%$ at the first milking day to $3.95 \%$ at the sixth day of lactation.

\section{Lactose content}

Lactose is the characteristic sugar of milk, and can be considered as the only carbohydrate present (Johnson, 1978). Lactose content ranged from $3.4 \%$ to $6.3 \%$ with a mean value $4.4 \%$ for colostrum (Table 1), which resembles that of Indian camel colostrum (4.3\%) (Ohri and Joshi, 1961), and somewhat higher than that of Saudi Arabia camel colostrum (2.7\%, Abu-Lehia, 1987). AbuLehia et al (1989) observed that at parturition lactose content was $2.68 \%$ and gradually increased to reach $4.4 \%$ at the third day, it continued to increase slightly after the third day of lactation until it reached $5.58 \%$ at the tenth day. Yagil and Elzion (1980) confirmed that lactose content of milk remained unchanged from first month of lactation to the end of lactation. It increased with an increase in availability of drinking water. Fluctuations were found when drinking water was chronically scarce i.e. availability of only $1 \mathrm{~h}$ aweek. Lactose content of mature camel milk ranged from $4 \%$ to $5.8 \%$ with a mean value $4.6 \%$ (Table 2 ). This is close to those found by Karim and Gooklani (1987) and Abu-Lehia (1987) for Irani and Saudi Arabia camel milk, respectively, but lower than those obtained by Bayoumi, (1990), Farah (1993) and Gnan and Sheriha (1986) for Egyptian (5.5\%), Kenya (5.3\%), and Libya (5.6\%) camel milks, respectively. It is worthy to mention here that Cook and Al-Torki (1975) reported the presence of intestinal lactase in adult humans in 
Saudi Arabia, and related this to traditional consumption of camel milk, which is the main source of milk intake for dessert dwellers.

\section{Total solids and moisture contents}

The range of total solids in camel colostrum was from $11.4 \%$ to $14.6 \%$ with a mean value $12.9 \%$ (Table 1). This is in agreement with the result mentioned by Johnson (1978), but considerably lower than those reported by Ohri and Joshi (1961) and Abu-Lehia et al (1989) for Indian and Saudi Arabia camel colostrum. The total solids content of mature camel milk ranged from $7.7 \%$ to $14.0 \%$ with a mean value $11.1 \%$. This is within the range of Sudanese camel milk (1014\%) obtained by Elamin and Wilcox (1992). Similar results were found by Abu-Lehia (1987) for Saudi Arabia camel milk being 11.3\%.

The water content of camel colostrum ranged from $86.17 \%$ to $88.62 \%$ with an average mean of $87 \%$. This is close to that reported by Johnson (1978), and is higher than that of Indian camel colostrum (78.8\%), (Abu-Lehia et al 1989). Water content of mature milk ranged from $86 \%$ to $92.3 \%$ with a mean value of $88.9 \%$. This result is comparable to those reported by Abu-Lehia (1987), Ahmed (1988) and Gorban and Izzeldin (1997). Present results are within the range of Sudanese camel milk (Sabiel, 1995). Yagil and Elzion (1980) reported that water content of camel milk is affected by water availability. When water is freely available, water content of milk will be $86 \%$, but when water is restricted the water content of milk rises to $91 \%$. This shows that the lactating camel loses its water to the milk in times of drought, which could be a natural adaptation in order to provide necessary fluid to the dehydrated calf.

\section{Ash content}

The range of ash content of camel colostrum was from $0.88 \%$ to $1.3 \%$ with a mean value $1.1 \%$. This is higher and lower than that found by Gorban and Izzeldin (1997), and Ohri and Joshi (1961), respectively. Ash content of mature camel milk ranged from $0.43 \%$ to $1.1 \%$ with mean value of $0.88 \%$. It is higher in comparison to cow milk, being $0.73 \%$, (Johnson, 1978). In general, ash content of camel milk could be greatly affected by drought conditions (Yagil and Elzion, 1980).

\section{Minerals content}

Milk minerals are mainly chlorides, phosphates, and citrates of $\mathrm{Na}, \mathrm{Ca}$, and $\mathrm{Mg}$. Although salts comprise $<\% 1$ of the milk, they influence the physical state and stability of milk proteins, particularly the caseinate (Farah, 1993). Tables (3 and 4) represent the mineral content of nutritionally essential elements of camel colostrum and mature milk, respectively. Calcium levels in colostrum, ranged between 60 to $159 \mathrm{mg} / 100 \mathrm{~g}$ with a mean value of $103 \mathrm{mg} / 100 \mathrm{~g}$, from 11.5 to 19.2 $\mathrm{mg} / 100 \mathrm{~g}$ with a mean value $15.4 \mathrm{mg} / 100 \mathrm{~g}$ milk for magnesium, 11.4 to $21.3 \mathrm{mg} / 100 \mathrm{~g}$ with a mean value $14 \mathrm{mg} / 100 \mathrm{~g}$ milk, for sodium, 111.4 to 165 $\mathrm{mg} / 100 \mathrm{~g}$ with a mean value $128 \mathrm{mg} / 100 \mathrm{~g}$ for potassium, 0.03 to 0.29 with a mean value of 0.25 $\mathrm{mg} / 100 \mathrm{~g}$ for iron and from 43.4 to $49.2 \mathrm{mg} / 100 \mathrm{~g}$ for inorganic phosphate. There are pronounced differences between values reported by Gorban and Izzeldin (1997) and our results. These differences could be due to various reasons such as variations in feed, breeds and analytical procedures. Yagil and Elzion (1980) found that the levels of $\mathrm{Na}$ and $\mathrm{K}$ in dromedary camel milk were directly affected by seasonal heat, and the level of water intake. Therefore, the concentration of these elements is a subject to variations depending on conditions prevailing at the time of animal milking.

The iron content is not affected to a great extent by its level in the diet; hence, the variations observed might be due to breed differences and /or analytical procedure.

The Ca content of mature camel milk ranged from 32.5 to $126.9 \mathrm{mg} / 100 \mathrm{~g}$ with a mean value $74.7 \mathrm{mg} / 100 \mathrm{~g}$, from 1 to $6.9 \mathrm{mg} / 100 \mathrm{~g}$ with a mean value $3.4 \mathrm{mg} / 100 \mathrm{~g}$ for magnesium, 14.8 to $71.1 \mathrm{mg} / 100 \mathrm{~g}$ with a mean value $42.4 \mathrm{mg} / 100 \mathrm{~g}$ for sodium, 50.9 to $186.2 \mathrm{mg} / 100 \mathrm{~g}$ with a mean value $136.6 \mathrm{mg} / 100 \mathrm{~g}$ for potassium, 0.001 to $0.39 \mathrm{mg}$ $/ 100 \mathrm{~g}$ with a mean value $0.18 \mathrm{mg} / 100 \mathrm{~g}$ for iron, 0.001 to $0.118 \mathrm{mg} / 100 \mathrm{~g}$ with a mean value 0.04 $\mathrm{mg} / 100 \mathrm{~g}$ for copper, 0.001 to $0.32 \mathrm{mg} / 100 \mathrm{~g}$ with a mean value $0.02 \mathrm{mg} / 100 \mathrm{~g}$ for manganese , 0.009 to $0.79 \mathrm{mg} / 100 \mathrm{~g}$ with a mean value $0.3 \mathrm{mg}$ $/ 100 \mathrm{~g}$ for $\mathrm{Zn}, 10$ to $54.4 \mathrm{mg} / 100 \mathrm{~g}$ with a mean value $38.4 \mathrm{mg} / 100 \mathrm{~g}$ for inorganic phosphate. Our data are in agreement with those of Mohamed (1990) for Ca (76 mg/100g), Mg (4 mg/100g), Cu $(0.03 \mathrm{mg} / 100 \mathrm{~g})$, and $\mathrm{Zn}(0.28 \mathrm{mg} / 100 \mathrm{~g})$ of Somali camel milk. Mehaia et al (1995) had the similar values for $\mathrm{P}(33.6 \mathrm{mg} / 100 \mathrm{~g})$, K (135 mg/100g), $\mathrm{Fe}(0.18 \mathrm{mg} / 100 \mathrm{~g})$. The Na level $(42.36 \mathrm{mg} / 100 \mathrm{~g})$, 
Table 1. Physicochemical characteristics of camel colostrums

\begin{tabular}{|lccc|}
\hline \multicolumn{1}{|c}{ Characteristics } & Mean values & Maximum values & Minimum values \\
\hline $\mathrm{pH}$ at $25^{\circ} \mathrm{C}$ & 6.19 & 6.33 & 6.02 \\
Density $\mathrm{g} / \mathrm{ml}$ & 1.041 & 1.050 & 1.032 \\
Fat \% & 3.1 & 3.92 & 0.40 \\
Protein \% & 4.95 & 6.95 & 3.71 \\
Lactose \% & 4.40 & 6.29 & 3.41 \\
Total solids \% & 12.88 & 14.55 & 11.38 \\
Non-fat total solids \% & 10.55 & 12.46 & 9.17 \\
Ash \% & 1.11 & 1.3 & 0.88 \\
Moisture \% & 87.08 & 88.62 & 86.17 \\
\hline
\end{tabular}

Table 2. Physicochemical characteristics of mature camel milk

\begin{tabular}{|lccc|}
\hline Characteristics & Mean values & Maximum values & Minimum values \\
\hline $\mathrm{pH}$ at $25^{\circ} \mathrm{C}$ & $6.6 \pm 0.047$ & 6.7 & 6.4 \\
Acidity \% & $0.133 \pm 0.02$ & 0.167 & 0.111 \\
Density $(\mathrm{g} / \mathrm{ml})$ & $1.028 \pm 0.003$ & 1.032 & 1.025 \\
Fat \% & $3.2 \pm 0.94$ & 5.28 & 1.13 \\
Protein \% & $2.4 \pm 0.34$ & 3.83 & 1.3 \\
Lactose \% & $4.60 \pm 0.41$ & 5.80 & 4.00 \\
Total solids \% & $11.08 \pm 1.23$ & 13.98 & 7.7 \\
Non-fat total solids \% & $7.88 \pm 0.53$ & 10.15 & 6.22 \\
Ash \% & $0.88 \pm 0.09$ & 1.09 & 0.43 \\
Moisture \% & $88.92 \pm 1.29$ & 92.3 & 86.02 \\
\hline
\end{tabular}


Table 3. Mineral content of camel colostrum (mg per 100g)

\begin{tabular}{|lccc|}
\hline \multicolumn{1}{|c}{ Element } & Mean values & Maximum values & Minimum values \\
\hline Calcium & 103.0 & 159.2 & 60 \\
Magnesium & 15.4 & 19.2 & 11.5 \\
Sodium & 14.0 & 21.3 & 11.4 \\
Potassium & 128.0 & 165 & 111.4 \\
Iron & 0.25 & 0.29 & 0.03 \\
Copper & 0.17 & 2.1 & 0.015 \\
Inorganic phosphate & 43.4 & 49.2 & 34.5 \\
\hline
\end{tabular}

Table 4. Mineral content of mature camel milk (mg per 100g)

\begin{tabular}{|lccc|}
\hline \multicolumn{1}{|c}{ Elements } & Mean values & Maximum values & Minimum values \\
\hline Calcium & 74.67 & 126.880 & 32.520 \\
Magnesium & 3.42 & 6.880 & 10.20 \\
Sodium & 42.36 & 71.060 & 14.820 \\
Potassium & 136.64 & 186.200 & 50.860 \\
Iron & 0.18 & 0.39 & 0.001 \\
Copper & 0.04 & 0.118 & 0.001 \\
Manganese & 0.02 & 0.323 & 0.001 \\
Zinc & 0.296 & 0.792 & 0.009 \\
Inorganic phosphate & 38.4 & 54.4 & 10.0 \\
\hline
\end{tabular}

is comparable to that obtained by Elamin and Wilcox (1992). In comparison to cow milk the level of potassium is slightly higher than that of cow milk (126mg/100g) (Mehaia et al 1995), the iron and copper content are almost three fold that of cow milk $(0.06 \mathrm{mg} / 100 \mathrm{~g}$ iron, 0.013 copper $)$. The $\mathrm{Zn}$ content is relatively close to that of cow milk $(0.49 \mathrm{mg} / 100 \mathrm{~g})$, but the Mn content was substantially higher than that of cow milk.

\section{REFERENCES}

Abdel Rahim, A.G. (1987). The chemical composition and nutritional value of camel and goats milk. World Review of Animal Production. 23(1): 9-12.
Abu-Lehia, I.H. (1987). Composition of camel milk, Michwissenschaft, 42(6):368-370.

Abu-Lehia, I.H. (1989). Physical and chemical characteristics of camel milk fat and its fractions.

Food Chemistry, 3: 261 - 271.

Abu-Lehia, I.H.; A. AL-Mohizea and M. EL-Bheri (1989). Physical and chemical characteristics of camel colostrum, Australian Journal of Dairy Technology 44:35-36.

Ahmed, M.M. (1988). The Analysis and Quality of Camel's Milk, p. 29. Higher Degree, Thesis, University, Reading, Reading, UK.

AOAC. (1995) Official Methods of Analysis, $14^{\text {th }}$ Ed., Chapter 33: 5-17, Association of Official Agricultural Chemists, Washington, DC, USA. 
APHA, (1972). American Public Health Associations Inc, Standard Methods for the Examination of Dairy Products, 13: 232, American Public Health Assoc., New York, USA.

Bayoumi, S. (1990). Studies on composition and rennet coagulation of camel's milk Kiefer, Millchwissenschafliche Forschungsberichte, 42 (1): 3-8.

Cook, G.C. and M.T. Al-Torki, (1975). High intestinal lactase concentrations in adult Arabs in Saudi Arabia. British Med. J. 5976: 135136.

Elamin, F.M. and G.J. Wilcox (1992). Milk composition of Majaheim camels. J. Dairy Sci. 75: 3155 - 3157.

FAO / WHO / OIE. (1992). Animal Health Yearbook. FAO Animal Production and Health Series No. 32, Food and Agriculture Organization, Rome. Italy.

Farah, Z. (1993). Composition and characteristics of some milk (review artictle). J. Dairy Research, 60: 603-626.

Gauthier-Pilters, H. and A.I. Dagg (1981). Husbandry and management of camels. British Veterinary J. 140(6): 618.

Gnan, S.O. and A.M. Sheriha (1986). Composition of Libyan camel's milk. Australia J. Dairy Technology, 41(1): 33-35.

Gorban, A.M.S. and O.M. Izzeldin (1997). Mineral content of camel milk and colostrum. J. Dairy Research, 64: 471-474.

Hagrass, A.E.; A.A. Hassan; K.A. Soryal; A.S. Mervat and S.A. El-Shabrawy (1987). Chemical composition of fat and butter of camel's milk. Egyptian J. Food Sci. 15: 15-25.

Johnson, A.H. (1978). The composition of milk, In: Fundamental of Dairy Chemistry, $2^{\text {nd }}$ Ed.: 125-209, Webb, B.H.; A.H. Johnson and J. Alford. The AVI Publishing Company Inc., West Port, CT, USA.
Karim, G. and I. Gooklani (1987). The gross components of camel milk in Turkman Sahara. J. Vet. Fac., University of Tehran, Iran. 42(1): 26. Ling, E.R. (1993). A Text Book of Dairy Chemistry, Vol. II, Practical, $3^{\text {rd }}$ Ed. 46-49, Champan and Hall, London, UK.

Mehaia, M.A.; M.A. Hablas; K.M. AbdelRahman and S.A. EL-Mougy (1995). Milk composition of Majaheim, Wadah and Hamra Camel's in Saudi Arabia. Food Chemistry, 52: 115 - 122.

Mohamed, A.M. (1990). Camel Milk, Chemical Composition, Characterization of Casein and Preliminary Trial of Cheese-making Properties. p. 30. Higher Degree Thesis. Swedish University of Agricultural Sciences Department of Chemistry, Uppsala, Sweden.

Ohri, S.P. and B.K. Joshi (1961). Composition of camel milk, Indian Vet. J. 38: 514-517.

Obsborne, D.R. and F., Voagt (1978). The Analysis of Nutrients in Food, Part 11, Section 6: 167. Academic Press, New York.

Sabiel, S.A.B. (1995). Studies on Milk Production of Camels under Nomadic System (Camelus dromedarius). p. 31. A thesis for Higher Degree, Faculty of Animal Production, University of Khartoum, Sudan.

SAS. (1997). SAS User's Guide Statistics, Version 6.12. SAS Institute Inc., Cary, NC., USA.

Wahba, A.; F. EL-Abbassy; I. Ismail and S.I. EL-Agamy (1988). Studies on Some physical, properties of camels milk. Egyptian J. Dairy Sci., 16: 19-22.

Wangoh, J.; Z., Farah and Z. Puhan (1998). Composition of milk from three camels breeds in Kenya during lactation. Milchwissenschaft 53(3): 136-139.

Yagil, R. (1987). Camel Milk - A Review. Intr. J. Anim. Sci., 2(2) :81-99.

Yagil, R. and Z., Elzion (1987). Effect of drought condition on the on the quality of camel milk. J. Dairy Res., 47: 159-162. 